\title{
Analysis of Trade Patterns and Economic Effect of China and Countries along the Belt and Road
}

\author{
Di Chao \\ Department of economics, Jincheng college, Nanjing University of Aeronautics \& Astronautics Nanjing, \\ Jiangsu, 211156
}

Key words. The Belt and Road; Foreign direct investment; Industrial upgrading; Optimization strategy

\begin{abstract}
With the development of China economy and establishment of foreign economic relations, the country launched and implemented the strategic deployment of "The Belt and Road", has made great achievements. Based on the "The Belt and Road" development background, it promoted the development of China foreign trade, and produced the corresponding economic effects, this paper presents the development status and the corresponding economic effects of China and the countries along the trade pattern from the perspective of "The Belt and Road".
\end{abstract}

\section{Introduction}

"The Belt and Road" refers to the Silk Road Economic Belt and maritime silk Economic Zone, covering 64 countries along, is a strategic planning put forward based on the development of the Silk Road of the Chinese nation in the history, on the complex political and economic situations, strengthening economic ties and development with the countries along the Belt and Road Initiative, achieving a win-win result through economic investment along the countries, is of great significance to promote the development of China foreign economic and trade.

\section{Analysis of trade pattern of China and the countries along the "The Belt and Road"}

With the development of national planning 11th Five-Year going global strategy, based on the background of "The Belt and Road", the direct economic investment of China to countries along the route and regions increases gradually, "The Belt and Road" includes a total of 64 countries along the route, divided into four areas specificly, namely North Asia, including Russia and Mongolia; Southeast Asia regions including Malaysia, India, Vietnam, Thailand and other 19 countries; Central Asia regions regions includeing 21 countries and the Middle East regions including 22 countries. Chinese economic investment to 64 countries along the "The Belt and Road " increased to \$72 billion in 2013 from \$1 billion 300 million in 2003 in ten years, the economic investment increased rapidly ${ }^{[1]}$.

However, there are relatively large differences in investment between different countries and regions. The largest areas of investment are Southeast Asia, South Asia, followed by Central Asia, West Asia, Middle East and finally, central and Eastern europe. In 2013, direct investment stock of China to South Asia and Southeast Asia reached \$41 billion 480 million, the flow was $\$ 7$ billion 700 million, accupied more than fifty percent of the total amount of China economy investment to all the way along the countries and regions. The investment country, the number of China's direct investment in The Belt and Road countries along the country has increased to 63 countries in 2013 years from 45 countries in 2003, in 64 countries China Belt and Road Initiative along the country contains only Bhutan China have yet to invest. But at present the country, China Belt and Road Initiative along the country's investment are more concentrated in Indonesia, Singapore, Mongolia, Russia, Burma and Kazakhstan and other countries ${ }^{[2]}$. The distribution of investment in countries and regions is quite different. For detailed analysis, see Table 1 below. 
Table I economic investment of China to distribution areas along the "The Belt and Road" of from 2003 years -2013 years (million)

\begin{tabular}{|c|c|c|c|c|c|c|c|}
\hline Year & $\begin{array}{c}\text { Direct } \\
\text { Investment }\end{array}$ & $\begin{array}{l}\text { The } \\
\text { World }\end{array}$ & $\begin{array}{l}\text { Total } \\
\text { along } \\
\text { the route }\end{array}$ & $\begin{array}{l}\text { Southeast } \\
\text { Asia } \\
\text { South Asia }\end{array}$ & $\begin{array}{c}\text { Central Asia } \\
\text { and West } \\
\text { Asia } \\
\text { Middle East }\end{array}$ & $\begin{array}{l}\text { North } \\
\text { Asia }\end{array}$ & $\begin{array}{l}\text { Central } \\
\text { and } \\
\text { Eastern } \\
\text { Europe }\end{array}$ \\
\hline \multirow[t]{2}{*}{2003} & flow & 28.55 & 2.02 & 1.31 & 0.29 & 0.35 & 0.07 \\
\hline & stock & 232.22 & 13.17 & 6.33 & 5.67 & 0.75 & 0.42 \\
\hline \multirow[t]{2}{*}{2005} & flow & 122.61 & 6.68 & 1.75 & 2.30 & 2.56 & 0.10 \\
\hline & stock & 572.06 & 33.90 & 15.12 & 11.81 & 5.96 & 0.54 \\
\hline \multirow[t]{2}{*}{2007} & flow & 265.06 & 32.46 & 19.04 & 6.24 & 6.74 & 0.35 \\
\hline & stock & 1179.11 & 96.08 & 52.02 & 20.22 & 20.14 & 2.92 \\
\hline \multirow[t]{2}{*}{2009} & flow & 477.95 & 45.28 & 27.77 & 10.76 & 6.25 & 0.51 \\
\hline & stock & 2457.55 & 200.68 & 155.30 & 45.51 & 34.62 & 5.25 \\
\hline \multirow[t]{2}{*}{2011} & flow & 685.84 & 99.29 & 68.14 & 17.90 & 11.67 & 1.57 \\
\hline & stock & 4247.81 & 412.34 & 250.19 & 93.56 & 56.50 & 12.09 \\
\hline \multirow[t]{2}{*}{2012} & flow & 777.33 & 133.22 & 65.41 & 48.25 & 16.89 & 2.67 \\
\hline & stock & 5319.41 & 576.56 & 324.60 & 147.95 & 78.43 & 16.58 \\
\hline \multirow[t]{2}{*}{2013} & flow & 927.39 & 126.34 & 77.31 & 32.47 & 14.11 & 2.45 \\
\hline & stock & 6604.78 & 720.15 & 414.83 & 176.13 & 109.36 & 19.84 \\
\hline
\end{tabular}

\section{Analysis of economic effect of China and countries along the "The Belt and Road" in the development of trade}

In the "The Belt and Road" under the background of China's deepening economic ties and trade along the country, its economy and trade has been rapidly developed, the countries along are "The Belt and Road" are generally in emerging market countries, with a larger market commodity you demand, which led to the development of the industry and Chinese export of commodities transfer, driven by economic benefits in China, mainly in the following two points.

The development of trade between China and the countriea along the The Belt and Road is conducive to the promotion of foreign investment in China, specifically in the implementation of the national "The Belt and Road" strategy, can strengthen China foreign direct investment. The reason for this phenomenon is the development mode of the foreign direct investment behavior under the China enterprises can not be limited to the domestic market environment and find the best resources in the broader market when the market allocation of resources and integration, so as to promote the upgrading of the industrial structure China enterprises, so has established some economic relation between the foreign direct investment and the upgrading of the industrial structure.

Through foreign direct investment on the impulse response analysis of the upgrading of industrial structure, we can see that the implementation of the adjustment of industrial structure to strengthen the direct investment to "The Belt and Road along the countries and regions. Through industrial upgrading of The Belt and Road along the countries and regions of the contribution of the data analysis we can see that the implementation of the "The Belt and Road" strategic objectives, the upgrading of the industrial structure of foreign direct investment contribution with the level of migration and development time presents the characteristics of the corresponding promotion. In this 
trend, driven by the China in the adjustment of industrial structure, from the traditional factor driven innovation driven is toward the direction of development, in the development of industrial structure promotes the development of relative surplus population more China labor intensive and production capacity of enterprises, including the development of some development is limited in some factors under the impression of the industry, develop foreign market development, to better promote the development of foreign direct investment, development of related industries to countries along the drive along the national development of related industries.

\section{Analysis of strategies of strengthening China's trade development under the background ofthe "Belt and Road Initiative"}

First of all, strengthening cooperation with countries along between the political economic and cultural links according to the specific conditions between different countries and China along political relations to make foreign countermeasures and measures, providing barrier free environment for the implementation of the strategy of going out of China enterprises to foreign countries, avoiding obstacles set in the business activities of enterprises for geopolitical reasons.

At the same time, the government in formulating plans for the development of economic and trade cooperation with countries along with the state of the economy should be base on local resources in accordance with the relevant China, optimal allocation and integration in the global principle, to provide a direction guiding role from the national policy level for China enterprises going out strategy and industry structure upgrade.

Actively establish and improve the development of foreign economic development environment of the Internet to promote direct investment to "The Belt and Road along the countries and regions. This can take the following specific strategies, first, the development strategy of "The Belt and Road" accurate positioning, from the global perspective to understand and grasp the interpretation, "The Belt and Road" economic construction from the overall development of the world economy point of view, to maximize the overall goal of actively seeking. Secondly, strengthen the construction of the relevant network system. Focus on the construction of the pilot project, according to the "The Belt and Road along the economic development from several important economic construction, requires good hardware and software conditions, geographical environment is good, the economic radiation to the surrounding areas in the economy pilot drive, make it become an important node in the development of strategy in a relatively short period of time ${ }^{[3]}$.

Thirdly, give full play to the important role of Hongkong in economic construction. Hongkong is an important gateway to China's economic development, and its economic and social development has been in a relatively perfect state, and highly integrated with the world economic standards. In 2010, the number of regional headquarters was 1285, reaching 1389 in 2014, and the number of offices in Hong Kong increased from 2353 to 2395 during the same period. According to statistical data, the share of China's foreign direct investment in Hongkong region is about sixty percent. With excellent software environment in the Hongkong area, overseas channel resources relatively wide, so it can become an important node of foreign trade development The Belt and Road along the country, give full play to regional advantages in Hongkong. Fourth in strengthening the infrastructure Belt and Road Initiative along the countries and regions of the construction work, the rapid development in the context of e-commerce, actively develop the electronic commerce construction along the border, to create a good environment for the development of foreign trade of the countries along The Belt and Road.

\section{Conclusion}

In the proposed and implementation of "The Belt and Road "great strategic background, Chinese stepped up along the country's economic investment, the two sides is a win-win economic relation, but at this stage, Chinese economic investment to countries along showed relatively strong regional differences, the establishment of the optimization measures should be taken to strengthen a new relationship between the two, from the perspective of the government as the development to 
optimize the external environment "The Belt and Road", strengthening the construction of an important stage and the relevant network, finally promote the development of foreign trade of China and the countries along in the " The Belt and Road "background.

\section{References}

[1] Zou Jialing, Liu Chunla, Yin Guoqing, et al. Chinese and "The Belt and Road "countries along the trade pattern and its contribution to economic progress [J]. Geographic science 2015, 34 (5): 598-605.

[2] Liu Xiaojun, Zhang Bin. The cooperation and development of "The Belt and Road" in China and countries along the cross-border electricity supplier logistics Chinese circulation economy [J]. 2016, 30 (5): 115-120.

[3]Yu Yang. Chinese and The Belt and Road along the country's trade patterns and economic contribution [J]. global market information review, 2016 ,4(10): 13-13.

[4] Tian Ze, Xu Dongmei. China's "The Belt and Road" along the country's investment efficiency and Countermeasures [J]. Economic review, 2016,11 (5): 84-89. 